\title{
Growth and Morphometric Characteristic of the Bivalve Callista chione Population in Timsah Lake, Suez Canal, Egypt
}

\author{
Abdel-Fattah A. Ghobashy ${ }^{1}$, Mohamed H. Yassien², Esraa E. AbouElmaaty ${ }^{2} *$ \\ ${ }^{1}$ Zoology Department, Faculty of Science, Suez Canal University, Ismailia, Egypt \\ ${ }^{2}$ Invertebrates Aquaculture Laboratory, Aquaculture Division, National Institute of Oceanography and Fisheries, \\ Gulfs of Suez and Aqaba branch, Attaqa, Suez, Egypt
}

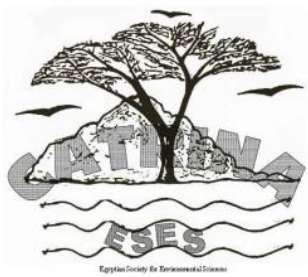

\begin{abstract}
This is the first attempt to study some biological aspects for the bivalve Callista chione in Egypt. The study of dimensional relationships assumes great importance in fishery biology researches. Studying the biological characteristics of $C$. chione is also essential for improving the state of current production and fishery management, as well as a base for introduction of its potential aquaculture. The growth of $C$. chione in Timsah Lake was studied in the period from June 2013 to August 2014 by the comparison of the rate of increase of one body parameter relative to that of the other parameter (allometry). The population characteristics of $C$. chione in Timsah Lake were studied depending on size frequency distribution to determine different age cohorts, growth parameters and mortality and exploitation rates. The results indicated that all morphometric relationships of $C$. chione showed a negative allometry. The length frequency analysis using FiSAT showed that $C$. chione population in the lake includes three age groups. The von Bertalanffy Growth Parameters; $L \infty, \mathrm{k}$ and to, were $6.25 \mathrm{~cm}, 0.530$ and $-0.68 \mathrm{y}$. The growth performance index was estimated as 1.316. The natural mortality, fishing mortality and total mortality were found to be $0.5,1.91$ and 2.41 year $^{-1}$. The estimated exploitation rate for C. chione from Timsah Lake was 0.792 year $^{-1}$ which indicates that it is over exploited. The results of this study will help in better fisheries and management. Strategies for a sustainable exploitation of smooth clams in Timsah Lake.
\end{abstract}

Keywords: $C$. chione ,Timsah lake, biological aspects.

\section{INTRODUCTION}

Timsah Lake is adjacent to Ismailia City, near the middle section of Suez Canal at a point $80 \mathrm{~km}$ South of Port Said (Kaiser et al., 2009). Bivalves of family Veneridae is the most successful organisms in Timsah Lake. They are commercially important and successful group of bivalves in Timsah Lake (Fouda and Abou Zied, 1990 and Ghobashy et al., 1992) Many species of this family are commercially marketed and cultured as an essential source of protein in various parts of the world (Valli et al., 1981; Ketchen et al., 1983 and Bourne, 1986); therefore, it was the subject of some research works to investigate its biology. Among these clams is the smooth clam Callista chione (Linnaeus, 1758); the species of this study. There are no previous studies on $C$. chione in Egypt, and this is the first work to investigate biological aspects of $C$. chione in Timsah Lake. $C$. chione is a relatively large (up to $5.8 \mathrm{~cm} \mathrm{long}$ ) and edible bivalve. It is commercially fished in Timsah Lake. The catches are sold in the markets and the restaurants with low price. $C$. chione is a shallowburrowing venerid bivalve. It inhabits sandy sediments in coastal waters from just offshore to a depth of about $130 \mathrm{~m}$ (Leontarakis and Richardson, 2005). It lives in fine and clean sand, from low tide down to $180 \mathrm{~m}$ (Tirado et al., 2002). It is widely distributed in Mediterranean and Atlantic waters, from the British Isles to the Moroccan Coast. In the Mediterranean Sea, $C$. chione is among the most abundant bivalve species inhabiting shallow soft bottomed shores and in some areas, the most prominent suspension-feeding species in terms of biomass (Leontarakis and Richardson, 2005). It is clear that $C$. chione found in Timsah Lake is an Antilessepsian migrant.

It penetrated Timsah Lake through Suez Canal. Often growth is estimated by measuring shell dimensions or the volume of the animal (Hibbert, 1977; Bailey and Green, 1988) because they are simple, non- destructive methods that can be easily completed in the field. The study of length-weight relationship and dimensional relationships assumes great importance in fishery biology researches. Measuring shell dimensions allows comparisons of the rates of increase of one body parameter relative to that of the other parameters by establishing allometric relationships which are essential for generating useful information for managing resources and understanding changes in environmental cond-itions (Palmer, 1990). The knowledge of growth rates is also necessary for modelling population dynamics, which, in turn, is crucial to support exploitation and mana-gement (Peharda et al., 2007) and to propose effective measures for the protection of the species (Katsane-vakis, 2007). Geographic latitude has a profound effect on the growth rate and age of bivalves (Moura et al., 2009). For example bivalves occupying warmer waters tend to have

\footnotetext{
* Corresponding author: esraa.elsayed@windowslive.com
} 
faster growth rates compared with populations in cooler waters (Metaxatos, 2004). Certain techniques for estimation the age and growth of bivalve populations may be more appropriate for one species than other (Daniel and James, 2013). The loss of individuals in a population can be estimated in terms of percentage of individuals that die (mortality rate). For commercial and edible species, overfishing is a source of mortality. The instantaneous total mortality rate is the sum of the instantaneous rate of fishing mortality and the instantaneous rate of natural mortality (Gosling, 2003). In order to improve the state of current production and fishery management, as well as a base for introduction of its potential aquaculture, a detailed study and evaluation of the biological characteristics of $C$. chione, specifically regarding its growth and reproduction is needed. This is why this paper includes information on the population characteristics depending on size frequency distribution of $C$. chione in Timsah Lake to determine different age cohorts, growth parameters and mortality and exploitation rates.

\section{MATERIALS AND METHODS}

\section{Study area}

Timsah Lake has a surface area of about $8 \mathrm{~km}^{2}$, an average depth of about 11 meters and a volume of about 90 million cubic meters of water (El-Sharkawy, 2012). The lake lies between latitude $30^{\circ} 32^{\prime}$ and $30^{\circ} 36^{\prime} \mathrm{N}$ and longitude $32^{\circ} 16^{\prime}$ and $32^{\circ} 21^{\prime} \mathrm{E}$ (Saad El-Din, 2014) (Fig. 1).

\section{Sample collection}

This study was carried out in the period from June 2013 to August 2014. C. chione is abundant in many sites in the lake but in lesser quantities than the other bivalve species. It is most concentrated in the eastern side of the lake which made it collected from different sites but mainly from North and South Islands, by local fishermen. Specimens of $C$. chione were collected monthly (Fig. 2), a total of 2436 specimens of C. chione were collected throughout the whole period of the study.

\section{Morphometric measurements}

Shell length (S.L.) and shell height (S.H.) were taken monthly for all specimens using a metal Vernier caliper (to the nearest $0.1 \mathrm{~cm}$ ) to obtain the different body dimensions (Fig. 3). Total wet weight (T.wt.), flesh weight (F.wt.). And shell weight (S.wt.) was assumed using digital balance (to the nearest $0.01 \mathrm{gm}$ ) to obtain different weights.

\section{Morphometric analysis}

Morphometric relationships were carried out as the relations between shell length, shell height, shell weight, flesh weight and total weight were studied by testing each pair of variables using potential allometric equation, $(\mathrm{Y}=\mathrm{a}+\mathrm{x} \mathrm{b})$ or power regression method $\left(\mathrm{Y}=\mathrm{a} \mathrm{x}{ }^{\mathrm{b}}\right)$.

1-Length-length relationships were described by a linear regression:

$$
\mathbf{Y}=\mathbf{a}+\mathbf{X} \mathbf{b}
$$

Where, $\mathrm{Y}$ is the dependent variable; $\mathrm{X}$ is the independent variable of the length $(\mathrm{cm})$; $a$ is a constant (the intercept of the regression line) and $b$ is the slope regression coefficient that gives the rate at which the variable $\mathrm{Y}$ alter with the variable $\mathrm{X}$.

2-Length-weight relationships were calculated using the equation:

$$
\mathbf{Y}=\mathbf{a} \mathbf{X}^{\mathbf{b}}
$$

Where, $\mathrm{Y}$ is a weight variable $(\mathrm{gm})$; $\mathrm{X}$ is the length variable (cm).

3-Weight-weight relationships were described by a linear regression:

$$
\mathbf{Y}=\mathbf{a}+\mathbf{X} \mathbf{b}
$$

Where, $\mathrm{Y}$ is the dependent variable; $\mathrm{X}$ is the independent variable of the weight $(\mathrm{gm})$.

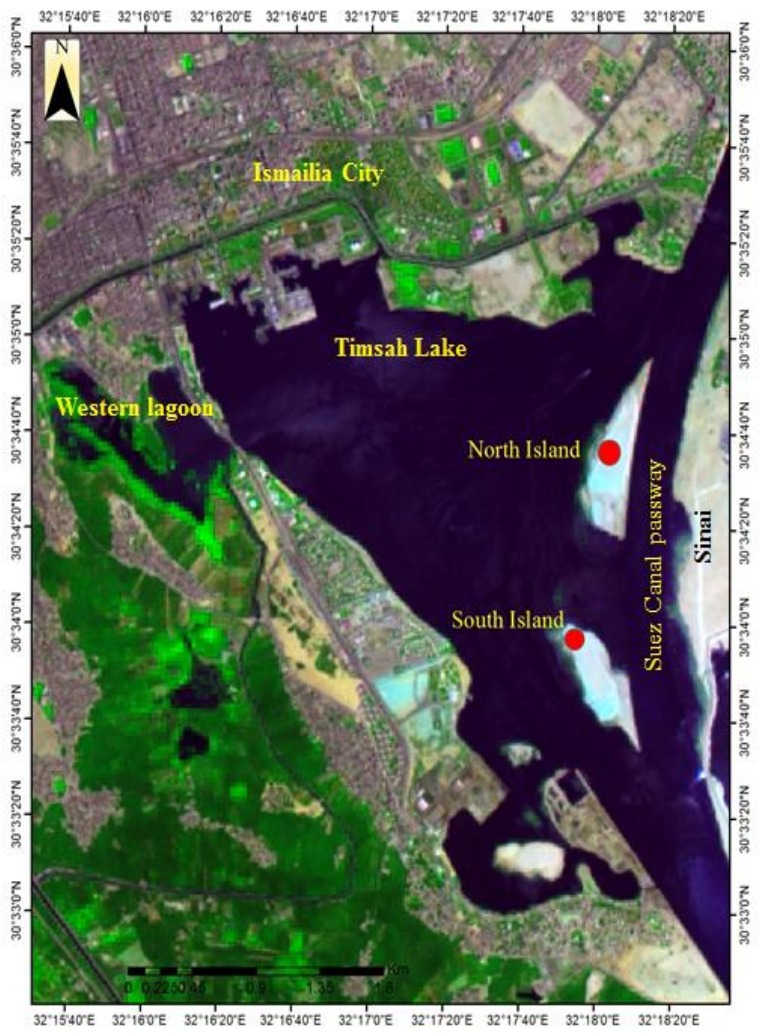

Figure (1): Location map of Timsah Lake, Suez Canal, Egypt.

\section{Statistical analysis}

The previously mentioned relationships between the morphometric parameters were carried out using linear regression in Microsoft Excel (2010).

\section{Length frequency distribution}

The shell length data obtained were grouped into shell length classes at $0.25 \mathrm{~cm}$ intervals and subsequently the frequency of each class was determined. 


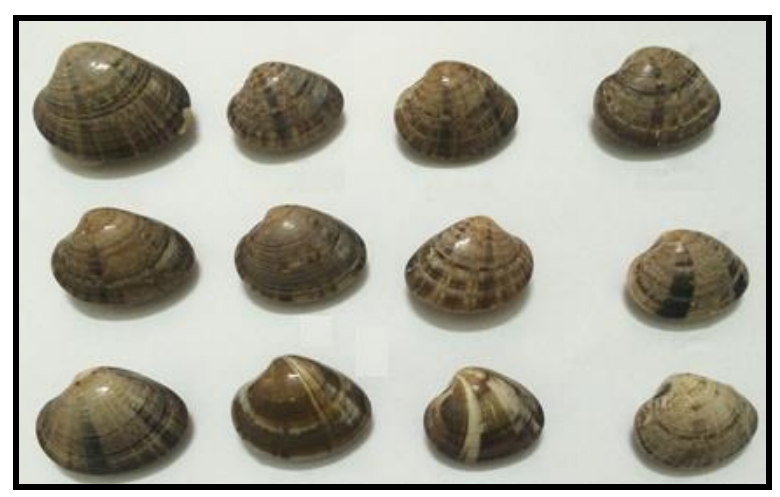

Figure (2): A photograph showing a sample of Callista chione in the laboratory after being sampled.

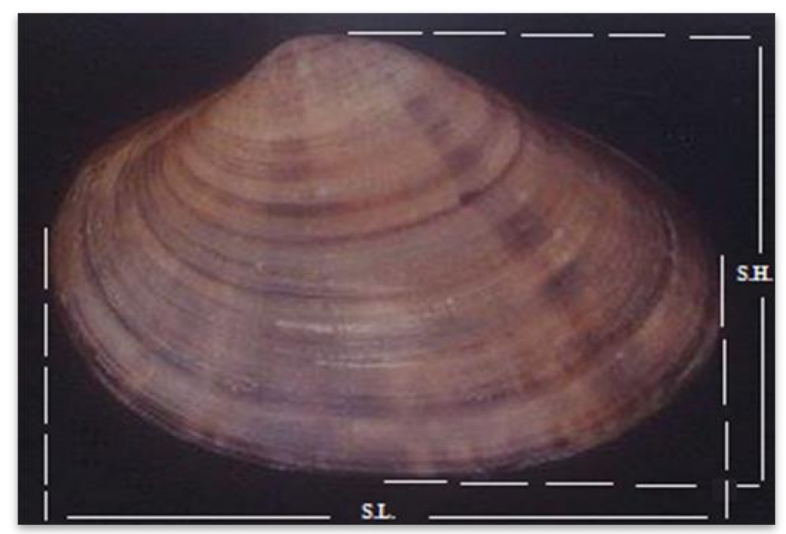

Figure (3): A Photograph of C. chione showing shell dimensions in frontal view as used in measurements.

\section{Age determination}

The length frequency distribution of $C$. chione was analyzed using routines in FAO-ICLARM Stock Assessment Tools (FISAT) II software package (Gayanilo et al., 2005). In order to identify the different age groups (cohorts) and the mean length of each group, Battacharya's method (Bhattacharya, 1967) incorporated in the FISAT II software was applied.

\section{Estimation of growth parameters}

Von Bertalanffy (1938) growth function (VBGF) was used in the present study. This model is popular with fishery scientists and its parameter $\mathrm{K}$ (growth rate) can be used to relate environmental conditions and clam growth. The Von Bertalanffy growth function (VBGF) was applied to the size at age data:

$$
\mathrm{L}_{\mathrm{t}}=\mathrm{L} \infty\left(1-\mathrm{e}^{-\mathrm{K}(\mathrm{t}-\mathrm{t})}\right)
$$

Where $L_{t}$ is the length at age $t ; L \infty$ is the asymptotic length (theoretical maximum length of the clam); $\mathrm{K}$ is growth coefficient (it determines how fast the clam approaches its $\mathrm{L} \infty$ ) and $\mathrm{t}_{0}$ is the initial condition parameter (the theoretical age at length zero).

The three parameters $\left(\mathrm{L} \infty, \mathrm{K}\right.$ and $\left.\mathrm{t}_{0}\right)$ need to be fitted by nonlinear regression. Powell-Wetherall method as modified by Pauly (1986), that is incorporated in the FISAT II software was employed in the estimation of the asymptotic Length $(\mathrm{L} \infty)$ of the Von Bertalanffy
Growth Function (VBGF) and the ratio of the total mortality to growth coefficient $(\mathrm{Z} / \mathrm{K})$ from the linear relationship. Von Bertalanffy growth constant $(\mathrm{K})$ was obtained using the "K- Scan" of ELEFAN-I model (Sparre and Venema, 1992) under the FiSAT II software. The initial condition parameter $t_{0}$ was estimated using the following equation:

$$
\mathrm{t}_{0}=\mathrm{t}+(1 / \mathrm{K})\left\{\operatorname{Lin}\left(1-\mathrm{L}_{\mathrm{t}} / \mathrm{L} \infty\right)\right\}(\text { Ricker, 1975) }
$$

\section{Estimation of growth performance index}

The growth performance index $(\Phi)$ (Munro and Pauly, 1983) was assumed. The estimated K and Lœ were used in the calculation using the following equations:

$\Phi=\log \mathrm{K}+2 \log \mathrm{L} \infty$

Where, $\Phi$ is the growth performance index; $\mathrm{k}$ is a growth coefficient and $\mathrm{L} \infty$ is the asymptotic length.

\section{Estimation of mortality rates}

The total mortality (Z) was calculated directly from the previous obtained data of the growth parameters ( $\mathrm{Z} / \mathrm{K}$ and $\mathrm{K}$ ), via multiplying the value of $\mathrm{Z} / \mathrm{K}$ by the value of $K$.

Natural mortality (M) was obtained using the method described by Taylor (1960) for bivalves:

$$
\mathrm{M}=2.996 / \mathrm{A}_{0.95}
$$

Where, $\mathrm{A}_{0.95}$ is the 95 percentile of the asymptotic length $(\mathrm{L} \infty)$.

Fishing mortality (F) was obtained directly by subtracting the natural mortality from the total mortality, where;

$$
\mathrm{Z}=\mathrm{M}+\mathrm{F} \quad \mathrm{OR} \quad \mathrm{F}=\mathrm{Z}-\mathrm{M}
$$

\section{Exploitation rate (E)}

The exploitation rate $(\mathrm{E})$ is the portion of total mortality due to fisheries; it can be calculated according to Sparre and Venema (1992):

$$
\mathrm{E}=\mathrm{F} / \mathrm{Z}
$$

\section{RESULTS}

\section{Morphometric parameters}

From the 2436 individuals of Callista chione that were collected from Timsah Lake during the period of study from June 2013 till July 2014, the mean shell length was $3.50 \pm 0.58 \mathrm{~cm}$ with a maximum value of $5.78 \mathrm{~cm}$ that was recorded in May while a minimum value of $1.07 \mathrm{~cm}$ was recorded in December (Fig. 4). The mean shell height was $2.60 \pm 0.44 \mathrm{~cm}$ with the highest value of $4.26 \mathrm{~cm}$ that was recorded in November and the lowest value of $0.70 \mathrm{~cm}$ was recorded in December. The mean total weight was $9.70 \pm 5.00 \mathrm{gm}$ with the greatest value of $33.96 \mathrm{gm}$ that was recorded in May and the smallest value of $1.05 \mathrm{gm}$ was recorded in December. The mean shell weight was $6.90 \pm 3.90 \mathrm{gm}$ with the topmost value of $21.70 \mathrm{gm}$ that was recorded in May and a minimal value of $0.30 \mathrm{gm}$ was recorded in December. The mean flesh weight was $2.40 \pm 1.15 \mathrm{gm}$ 
with a maximum value of $7.90 \mathrm{gm}$ that was recorded in May while the minimum value of $0.20 \mathrm{gm}$ was recorded in December (Table 1).

\section{Morphometric relationships}

The results showed linear models for length-length and weight-weight relationships and power models for length-weight relationships. All the relationships showed a positive significant relationship $(\mathrm{P}<0.001)$. The correlation coefficient $\left(\mathrm{R}^{2}\right)$ showed a good fitted data and the exponent $\mathrm{b}$ value indicated a negative allometry (Fig.4 and Table 2).

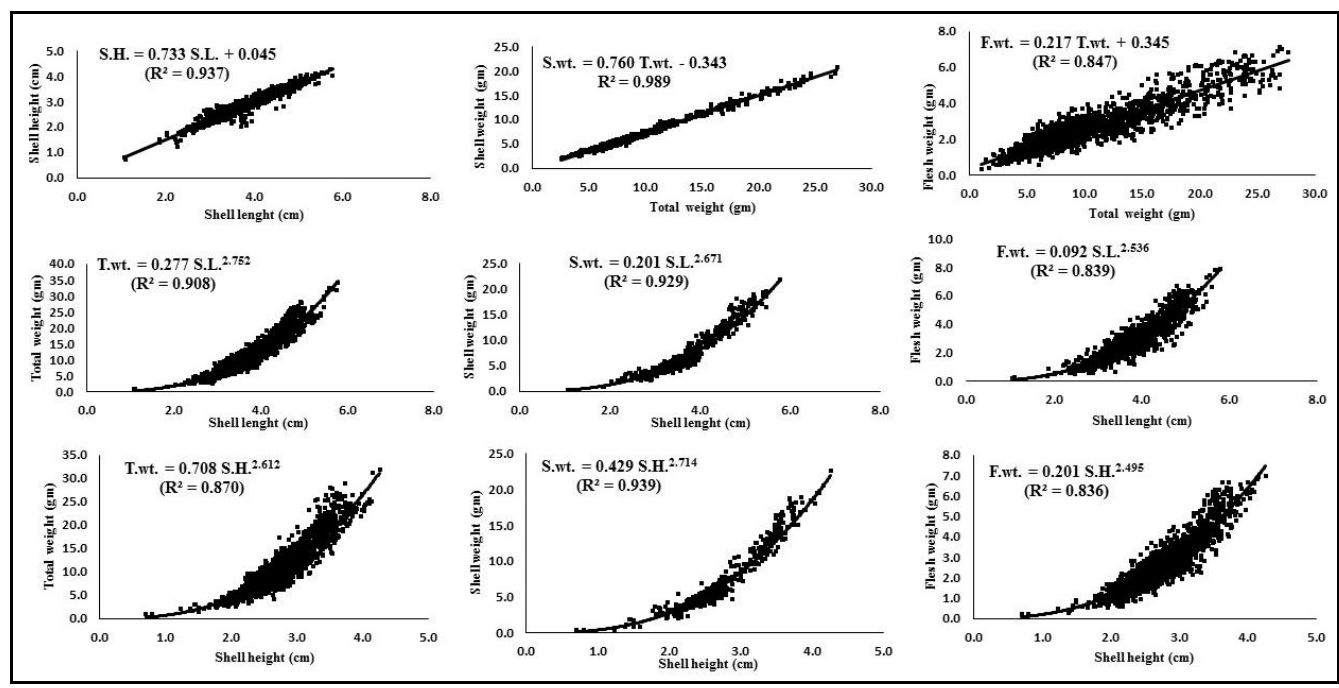

Figure (4): Morphometric relationships of C. chione collected from Timsah Lake in the period from June 2013 to July 2014.

Table (1): Mean, standard deviation (S.D.), minimum and maximum values of the morphometric parameters (S.L., S.H., T.wt., S.wt. and F.wt.) for Callista chione collected from Timsah Lake in the period from June 2013 to July 2014.

\begin{tabular}{lccc}
\hline \hline Morphometric parameter & Mean \pm S.D. & Maximum value & Minimum value \\
\hline Shell length $(\mathbf{c m})$ & $3.50 \pm 0.58$ & 05.78 & 1.07 \\
Shell height $(\mathbf{c m})$ & $2.60 \pm 0.44$ & 04.26 & 0.70 \\
Total weight $(\mathbf{g m})$ & $9.70 \pm 5.00$ & 33.96 & 1.05 \\
Shell weight $(\mathbf{g m})$ & $6.90 \pm 3.90$ & 21.70 & 0.30 \\
Flesh weight $(\mathbf{g m})$ & $2.40 \pm 1.15$ & 07.90 & 0.20 \\
\hline \hline
\end{tabular}

Table (2): Linear regression results for the relationships between the morphometric parameters (S.L., S.H., T.wt., S.wt. and F.wt.) for $C$. chione collected from Timsah Lake in the period from June 2013 to July 2014.

\begin{tabular}{lcccccccc}
\hline \hline \multirow{2}{*}{ Morphometric relationship } & \multirow{2}{*}{$\mathbf{a}$} & $\mathbf{b}$ & \multirow{2}{*}{$\mathbf{R}^{\mathbf{2}}$} & \multirow{2}{*}{ S.E. } & \multirow{2}{*}{ P-Value } & \multirow{2}{*}{ t-value } & \multicolumn{2}{c}{ 95\% Confidence interval } \\
\cline { 7 - 9 } & & & & & & Lower & Upper \\
\hline Shell length-shell height & 0.045 & 0.733 & 0.937 & 0.004 & $<0.001$ & 189.6 & 0.0174 & 0.0719 \\
Shell length-total weight & 0.277 & 2.752 & 0.908 & 0.018 & $<0.001$ & 155.4 & 0.2649 & 0.2892 \\
Shell length-shell weight & 0.201 & 2.671 & 0.929 & 0.028 & $<0.001$ & 093.9 & 0.1868 & 0.2158 \\
Shell length-flesh weight & 0.092 & 2.536 & 0.839 & 0.023 & $<0.001$ & 112.4 & 0.0867 & 0.0969 \\
Shell height-total weight & 0.708 & 2.612 & 0.870 & 0.020 & $<0.001$ & 127.7 & 0.6809 & 0.7362 \\
Shell height-shell weight & 0.429 & 2.714 & 0.939 & 0.030 & $<0.001$ & 089.5 & 0.4042 & 0.4561 \\
Shell height-flesh weight & 0.201 & 2.495 & 0.836 & 0.022 & $<0.001$ & 111.5 & 0.1924 & 0.2095 \\
Total weight-shell weight & -0.343 & 0.760 & 0.989 & 0.003 & $<0.001$ & 248.1 & -0.4092 & -0.2763 \\
Total weight-flesh weight & 0.345 & 0.217 & 0.847 & 0.001 & $<0.001$ & 116.1 & 0.3052 & 0.3845 \\
\hline \hline
\end{tabular}

S.E. = standard error of slope; all regressions significant at $\mathrm{P}<0.001$.

\section{Length frequency distribution}

The length frequency distribution of $C$. chione was graphically represented in figure (5). Less than $25 \%$ of the individuals were represented in class intervals from 1.25 to $2.75 \mathrm{~cm}$. About $50 \%$ of the individuals were represented in class intervals from 3 to $3.5 \mathrm{~cm}$. More than $25 \%$ of the individuals were represented in class intervals from 3.75 to $5.75 \mathrm{~cm}$.

\section{Age determination}

Bhattacharya's analysis allowed the separation of three different cohorts in the population of $C$. chione in Timsah Lake (separation index $>2$ ). The mean lengths of these cohorts were; $3.38 \mathrm{~cm}$ (the first age group), $4.66 \mathrm{~cm}$ (the second age group) and $5.50 \mathrm{~cm}$ (the third age group). The main bulk of the catch was represented in the first age group (Fig. 6). 


\section{Growth parameters}

Powel-Wetherall method was represented in figure (7) where the following estimates were obtained. $L \infty=$
$6.25 \mathrm{~cm}$ and $\mathrm{Z} / \mathrm{K}=3.689$. Von Bertalanffy growth constant $(\mathrm{K})$ was found to be 0.530 year $^{-1}$. The value of $\mathrm{t}_{0}$ for C. chione was determined for the three age groups as 0.68 year.

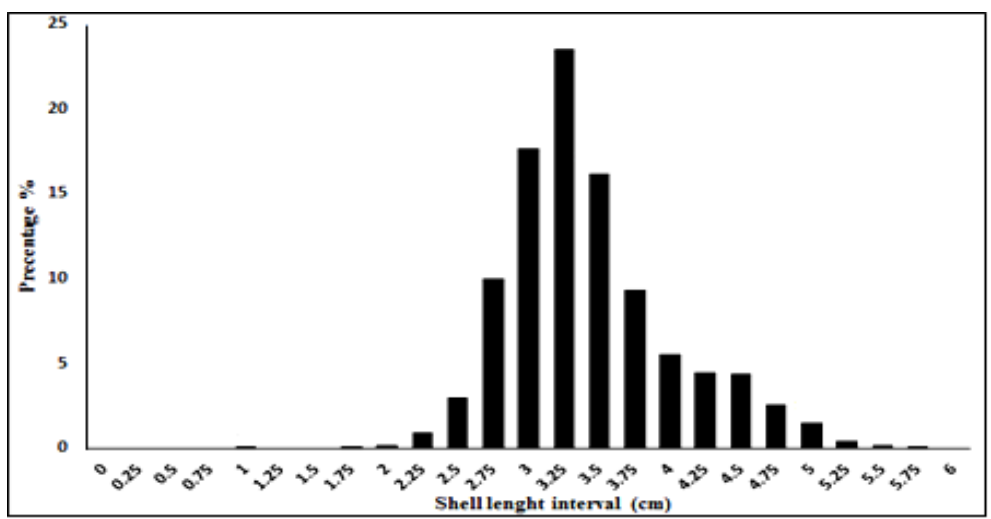

Figure (5): The length frequency distribution histogram for all samples of $C$. chione collected from Timsah Lake in the period from June 2013 to July 2014.

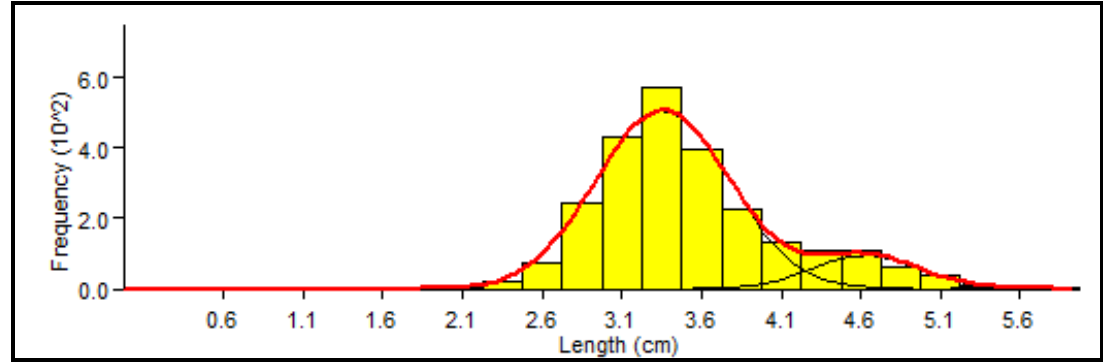

Figure (6): Age groups determination by length frequency distribution for the population of $C$. chione collected from Timsah Lake in the period from June 2013 to July 2014.
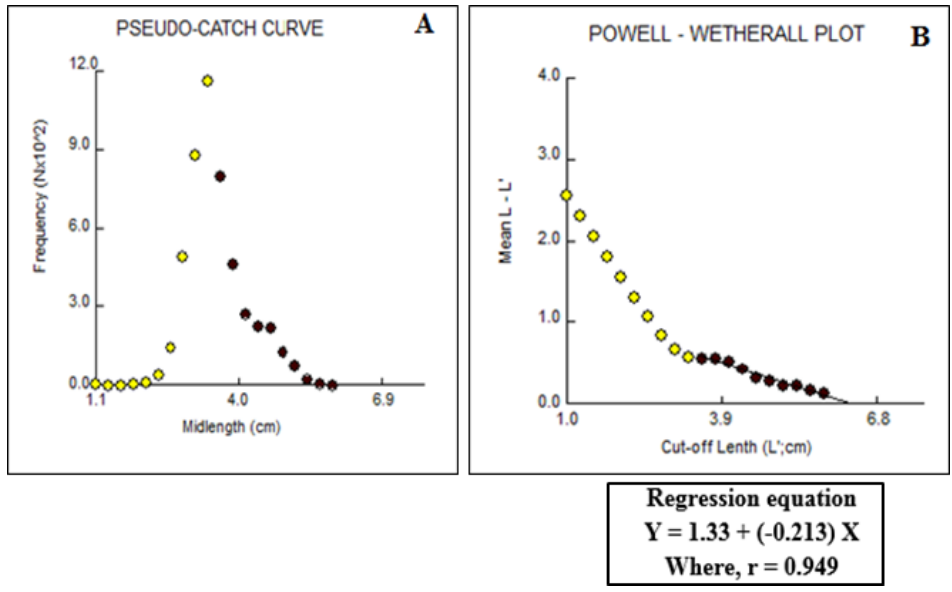

Figure (7): A, Pseudo-catch curve identifying the age group fully recruited to the fishery and $\mathbf{B}$, Powell-Wertherall plot to estimate $\mathrm{L} \infty$ and $\mathrm{Z} / \mathrm{K}$.

\section{Growth performance index}

The growth performance index was calculated using the parameters of Von Bertalanffy growth equation; $\mathrm{L} \infty=6.25 \mathrm{~cm}$ and $\mathrm{K}=0.530$ year $^{-1}$.

$\Phi=\log _{10} 0.530+2 \log _{10} 6.25$ $\Phi=1.316$

\section{Mortality rates}

The total mortality coefficient of $C$. chione in Timsah Lake was obtained; $\mathrm{Z}=2.41$ year $^{-1}$. The natural mortality coefficient was; $M=0.5$ year $^{-1}$ and the instantaneous fishing mortality coefficient was; $\mathrm{F}=1.91$ year $^{-1}$ 


\section{Exploitation rate $(\mathrm{E})$}

The exploitation rate of $C$. chione population in Timsah Lake was found to be; $E=0.792$ year $^{-1}$. These results show that the fisheries of $C$. chione in Timsah Lake are highly exploited $(\mathrm{E}>0.5)$.

\section{DISCUSSION}

The growth of $C$. chione was firstly studied by the comparison of the rate of increase of one body parameter relative to that of the other parameter (allometry). The term "allometry" was introduced by Huxley and Teissier (1936) and then it has been applied to many bivalves including several species of clams as $C$. chione (Gaspar et al., 2001 and 2002; Leontarakis and Richardson, 2005 and Damianidis et al., 2010). The present study revealed that, all morphometric relationships of $C$. chione showed a negative allometry which coincides with Valli et al. (1983) who also stated its negative allometry. It is in apparent contradiction with some studies in other geographical areas. Gasper et al. (2001 and 2002) and Damianidis et al. (2010) confirmed its isometric growth while Leontarakis and Richardson (2005) pointed to its positive allometry. Negative allometry indicates that the dimension $\mathrm{X}$ is increasing relatively faster than Y (Gould, 1966). The estimated values of a, b and R2 of the present morphometric relationships were compared to those estimated in other areas (Table 3).

In shell length-total weight relationship, length was increasing faster than weight. The findings are corroborated by Wilbur and Owen (1964), who stated that, the values of equilibrium constant (b) lies between 2.4 and 4.5 in most of the bivalves. When $b$ value is $<3$, this means that the large specimens have changed their body shape to become more elongated or small specimens were in better nutritional condition at the time of sampling (Froese, 2006). Leontarakis and Richardson (2005) findings contradict with the present study in the (b) values while $\mathrm{R}^{2}$ values of the relationships are nearly the same. Damianidis et al. (2010) studied the seasonal shell length-total weight relationships in Agean Sea where the average value of (b) of the relationships does not coincide our results. Kilada (2010) studied the different morphometric relationships for two species belong to the same family of the studied species; Ruditapes decussatus and Gafrarium pectinatum that collected from the same area of study (Timsah Lake) where the (b) values are in agreement with the present findings.

This may confirm that, the allometry coefficient (b) differs according to the different hydrological and sedimentological features in various geographical areas (Gaspar et al., 2002).Variations in allometry of bivalves are linked to species, physiological characteristics, and habitat conditions (Gosling, 2003). In consequence, the results of the present study concerning the relationships between different shell dimensions and body weights are specific and might be an indication for specific environmental factors in the lake. In the present study, the age determination of $C$. chione depends on lengthfrequency distribution analysis of specimens collected from Timsah Lake. Three different cohorts in the population of $C$. chione in Timsah Lake were identified. The mean lengths of these cohorts were; $3.38 \mathrm{~cm}$ (the first age group), $4.66 \mathrm{~cm}$ (the second age group) and $5.50 \mathrm{~cm}$ (the third age group). The main bulk of the catch is belonging to the age group I. Despite not having estimated growth parameters for the same species in Egypt, most of the previous age determination studies conducted on $C$. chione in other regions in Mediterranean and Atlantic show no similar results. In the Maresme coast (North-western Mediterranean Sea), Baeta et al. (2014) found that $90 \%$ of the population corresponds to ages below 4 years which is closely similar to the present findings.

The older individuals in this area; represent a small portion of the population. In contrast with the maximally reached age of $C$. chione in other regions in the Mediterranean and Atlantic. Hall et al. (1974) estimated the maximum age of the species to be 18 years in the Adriatic Sea. Forster (1981) mentioned it as a long-lived bivalve that can live for 40 years in coastal waters of the U.K. In the Aegean Sea, Metaxatos (2004) observed that most of the smooth clam's $C$. chione were between 5 and 8 years old. In Thracian Sea, Northeastern Mediterranean, Leontarkis and Richardson (2005) found that the longevity of smooth clam $C$. chione ranged between 12 to 16 years and $C$. chione of 6 to 9 years old represent more than the $10 \%$ of the population. In Portugal, Moura et al. (2009) reported that it had reached 17 years. In the Adriatic Sea, Ezgeta-Balic et al. (2011) found that a high proportion (32\%) of the population located in places with none or low fishing pressure were older than 15 years. In the present study, the shell length of $C$. chione ranged between 1.1 to $5.8 \mathrm{~cm}$ and the mean shell length was $3.5 \mathrm{~cm}$. In the Maresme coast (Northwestern Mediterranean Sea), Baeta et al. (2014) carried out his studies on the $C$. chione population by year 2004 and 2010 with mean shell length 3.1 and $2.8 \mathrm{~cm}$ respectively, which are close to the mean shell length of $C$. chione in this study and this may elucidate the similarity of most of his findings to the present one.

The range of shell length in the present study is relatively smaller than that of $C$. chione investigated in the previous works in different areas. This may be due to that, most of these areas lie in higher latitude (lower temperature) so, the individuals there grow slower and reach higher shell length than in temperate area and consequently has higher maximum reached age. 
Table (3): Morphometric relationship parameters for $C$. chione collected from different locations.

\begin{tabular}{|c|c|c|c|c|c|c|}
\hline Author & Location & Studied species & $\mathbf{a}$ & b & $\mathbf{R}^{2}$ & Relatioship \\
\hline Leontarakis and & \multirow{3}{*}{ Greece } & \multirow{3}{*}{ C. chione } & 0.660000 & $1.0300 \pm(0.006)$ & 0.956 & Shell height-shell length \\
\hline \multirow[t]{2}{*}{ Richardson (2005) } & & & 0.000087 & $3.0800 \pm(0.033)$ & 0.941 & Shell length -shell weight \\
\hline & & & 0.000015 & $3.3000 \pm(0.043)$ & 0.859 & Shell length-flesh weight \\
\hline Damianidis et al. (2010) & Portgul & C. chione & 0.000200 & $3.0063 \pm(0.280)$ & 0.840 & Shell length-total weight \\
\hline \multirow[t]{4}{*}{ Kilada et al. (2010) } & \multirow{4}{*}{$\begin{array}{c}\text { Timsah } \\
\text { Lake, } \\
\text { Egypt }\end{array}$} & R. decussatus & 5.040000 & $1.9000 \pm(0.066)$ & 0.860 & Shell height-shell length \\
\hline & & & 0.000100 & $2.8300 \pm(0.080)$ & 0.890 & Shell length-total weight \\
\hline & & G. pectinatum & 5.640000 & $2.2500 \pm(0.060)$ & 0.870 & Shell height -shell length \\
\hline & & & 0.001000 & $2.5300 \pm(0.057)$ & 0.900 & Shell length-total weight \\
\hline \multirow[t]{7}{*}{ Present study } & Timsah & C. chione & 0.045000 & $0.7330 \pm(0.004)$ & 0.937 & Shell length-shell height \\
\hline & Lake, & & 0.277000 & $2.7520 \pm(0.018)$ & 0.908 & Shell length-total weight \\
\hline & Egypt & & 0.201000 & $2.6710 \pm(0.028)$ & 0.929 & Shell length-shell weight \\
\hline & & & 0.092000 & $2.5360 \pm(0.023)$ & 0.839 & Shell length-flesh weight \\
\hline & & & 0.708000 & $2.6120 \pm(0.020)$ & 0.870 & Shell height-total weight \\
\hline & & & 0.429000 & $2.7140 \pm(0.030)$ & 0.939 & Shell height-shell weight \\
\hline & & & 0.201000 & $2.4950 \pm(0.022)$ & 0.836 & Shell height-flesh weight \\
\hline
\end{tabular}

In U.K., Forster (1981) stated that the length of $C$. chione in his study ranged from 7.3 to $9.4 \mathrm{~cm}$. In Thracian Sea, Northeastern Mediterranean, Leontarakis and Richardson (2005) investigated $C$. chione of shell length ranged between 1.6 and $7.2 \mathrm{~cm}$. In Portugal, Moura et al. (2009) made his studies on C. chione of shell length ranging between 2.27 and $9.25 \mathrm{~cm}$. In Aegean Sea, Damianidis et al. (2010) made his studies on seasonal collected samples from two different sites in Thermaikos Gulf, where their shell length ranged from 4.7 to $7.5 \mathrm{~cm}$ in Platamonas and from 2.95 to $7.30 \mathrm{~cm}$ in Sani. In the Eastern Adraiatic Sea, Ezgeta-Balic et al. (2011) made his studies on $C$. chione of shell length ranged between 3 and $8.8 \mathrm{~cm}$. In the present study, it was observed that $C$. chione grows quickly during the first year $(1.28 \mathrm{~cm} /$ year $)$ and then the growth rate decreases during the second year $(0.84 \mathrm{~cm} /$ year $)$. Hall et al. (1974) stated that $C$. chione grew twice fast $(0.93$ $\mathrm{cm}$ ) during the third year of their life than during their seventh or any later year $(0.47 \mathrm{~cm})$. Keller et al. (2002) confirmed that the growth rate of $C$. chione was relatively fast during the first three or four years of life and an apparent decrease in growth rate occurred after the fourth year. Damianidis et al. (2010) confirmed that this species has the fastest growth rate in its first years of life which was then reduced and Ezgeta-Balic et al. (2011) confirmed that $C$. chione growth rate is reduced with increasing age, as he found that $C$. chione grew rapidly during the first five years with a subsequent decrease in growth rate with increasing the age.

It was noticed that $C$. chione in Timsah Lake, grows in a similar fashion and it does not exceed the three age groups. The lowest reached age group compared with the same species in most of the comparative areas may be due to distinct environmental conditions prevailing in these areas. In the present study, asymptotic shell length $(\mathrm{L} \infty)$ that was calculated to be $6.25 \mathrm{~cm}$ is similar to the result obtained from the Thracian Sea, Northeastern Mediterranean by Leontarakis and Richardson (2005) as $6.2 \mathrm{~cm}$. It is much smaller than that estimated by Forster
(1981), Metaxatos (2004), Moura et al. (2009), Damianidis et al. (2010), Ezgeta-Balic et al. (2011) and Baeta et al. (2014). C. chione in the Mediterranean had a growth rate $(\mathrm{K})$ of 0.24 year $^{-1}$ compared with a similar population in the Atlantic Ocean with growth rates between 0.15 and 0.18 year $^{-1}$ (Moura et al., 2009). In the present study the growth rate $(\mathrm{K})$ was calculated to be 0.53 year $^{-1}$ which is higher than all other compared areas except that recorded in Thermaikos Gulf (In Sani) by Damianidis et al. (2010) as 0.66 year $^{-1}$.

The obtained $\mathrm{K}$ value for $C$ chione in the present study indicates a relatively high growth rate. This means that $C$. chione reaches its maximum length faster. This could be attributed mainly to the temperature in Timsah Lake. The growth performance index that was estimated in Timsah Lake as 1.316 is similar to that in Spain but lower than that estimated in U.K., Greece, Portugal and Adriatic Sea. (3). As C. chione that found in Timsah Lake undergoes an Anti-lessepsian migration, where the Mediterranean species migrate from colder areas through the Suez Canal in the Red Sea direction, this may reveal the reason of the lower value of growth performance index. This means that the authentic environment is more appropriate and suitable for the growth of $C$. chione than Timsah Lake. The mortality and exploittation rates are important parameters in population dynamics. In the present study, the natural mortality (M) which is defined as the mortality caused by all possible causes of death except fishing (Osman, 2016) was found to be 0.5 year $^{-1}$. Fishing mortality $(\mathrm{F})$ which is the death caused by fishing was found to be 1.91 year $^{-1}$. Both (M) and $(\mathrm{F})$ is giving the total mortality $(\mathrm{Z})$, it was estimated to be 2.41 year $^{-1}$. The exploitation rate is used to assess whether a stock is overexploited or not. This is based on the assumption that a stock is optimally exploited at $\mathrm{E}=0.5$ when $(\mathrm{F})$ equals $(\mathrm{M})$ (Gulland, 1971). The estimated exploitation rates for $C$. chione from Timsah Lake were 0.792 year $^{-1}$ which indicates that it is over exploited. It is observed that $C$. chione in the present study has suffered an intensive fishing 
pressure and therefore there is a high exploitation rate. This may be a reason for the decrease in the mean size of the population compared with the same population in many other areas. This interpretation corresponds to the situation of $C$. chione population in the Maresme coast (Northwestern Mediterranean Sea), where the population had suffered an intensive fishing pressure for decades. This fishing pressure led to progressive decrease in the mean size of the population which was followed by the collapse of the population there as mentioned by Dr. Marc Baeta (Postdoctoral Researcher) (ETC-ULS SGRInterfase, Department de Geografia, Autonomous University of Barcelona, Edifici B 08193 Bellaterra, Cerdanyola del valles) (personal communication).

\section{REFERENCES}

BAETA, M., M. RAMÓN AND E. GALIMANY. 2014. Decline of a Callista chione Bivalvia: Veneridae) bed in the Maresme coast (Northwestern Mediterranean Sea). Ocean and Coastal Management 93: $15-25$.

BAILEY, R.C. AND R.H. GREEN. 1988. Within-basin variation in the shell morphology and growth rate of fresh water mussel. Canadian Journal of Zoology 66: 1704-1708.

BHATTACHARYA, C.G. 1967. A simple method of resolution of a distribution into Gaussian components. Biometrics 23: 115-135.

BOURNE, N. 1986. Distribution, reproduction and growth of Manila clam, Tapes philippinarum (Adams and Reeves), in British Columbia. Journal of Shellfish. Research 2: 47-54.

DAMIANIDIS, P., P.K. KARACHLE AND C. CHINTIROGLOU. 2010. Biology of Callista chione L., 1758 in Thermaikos Gulf (Aegean Sea). Rapport Commission international Mer Méditerranée 39: 486.

DANIEL, A. AND W.G. JAMES. 2013. Age Determination and Growth Rate of the Freshwater Clam Galatea paradoxa (Born 1778) from the Volta River Estuary, Ghana. Journal of Aquatic Science 1(2): 3138.

EL-SHARKAWY, A. 2012. Second generation multiresolution techniques for edge detection and feature extraction from 8-Bands high resolution satellite Imagery. Ph. D. Thesis University of Calgary, Canada $185 \mathrm{p}$.

EZGETA-BALIC' D., M. PEHARDA, C.A. RICHARDSON, M. KUZMANIC', N. VRGOC ${ }^{`}$ AND I. ISAJLOVIC'. 2011. Age, growth, and population structure of the smooth clam Callista chione in the eastern Adriatic Sea. Helgoland Marine Research 65: 457-465.

FORSTER, G.R. 1981. The age and growth of Callista chione. Journal of the Marine Biological Association of the United Kingdom 61: 881-883.

FOUDA, M.M AND M.M. ABOU-ZIED. 1990. Bivalves of the Suez Canal Lakes. Proceedings of the
Zoological Society, Arab Repuplic of Egypt 21: 231240.

FROESE, R. 2006. Cube law, condition factor and weight-length relationship: History, meta-analysis and recommendations. Journal of Applied Ichthyology, 22(4): 241-253.

GASPAR, M.B., M.D. DIAS, A. CAMPOS, C.C. MONTEIRO, M.N. SANTOS, A. CHÍCHARO AND L. CHÍCHARO. 2001. The influence of dredge design on the catch of Callista chione (Linnaeus, 1758). Hydrobiologia 465: 153-167.

GASPAR, M.B., M.N. SANTOS, P. VASCONCELOS AND C.C. MONTEIRO. 2002. Shell morphometric relationships of the most common bivalve species (Mollusca: Bivalvia) of the Algarve coast (Southern Portugal). Hydrobiologia 477: 73-80.

GAYANILO, F.C., P. SPARRE AND P. PAULY. 2005. The FAO-ICLARM Stock Assessment Tools (FiSAT). Revised version. User's manual. FAO Computerized Information Series (Fisheries), No. 7 (pp. 168) Rome: Worldfish Center, FAO.

GHOBASHY, A.F. A., S.Z. MOHAMMED, H.R. GABR AND A.R. BRAND. 1992. Community structure and seasonal variation of Mollusca in Lake Timsah (Suez Canal). Journal of the Egyptian German Society of Zoology 7(B): 145-160.

GOSLING, E. 2003. Bivalve Molluscs: Biology, Ecology and Culture, Fishing News Books: Oxford, U. K. ISBN. 978047674949.

GOULD, S.J. 1966. Allometry and size in ontogeny and phylogeny. Biological Reviews 41: 587-640.

GULLAND, J.A. 1971. The fish resources of the ocean. West Byfleet, Surrey, Fishing News (Books) Ltd., for FAO, 225 p. Review edition of FAO Fisheries technical paper 97: 425 p. (1970).

HALL, C.A.J., W.A. DOLLASE AND C.E. CORBATÓ. 1974. Shell growth in Tivela stultorum (Mawe, 1823) and Callista chione (Linnaeus, 1758) (Bivalvia): latitudinal differences, and diminution with age. Palaeogeography, Palaeoclimatology, Palaeoecology 15: 33-61.

HIBBERT, C.J. 1977. Growth and survivorship in a tidal-flat population of the bivalve Mercenaria mercenaria from Southampton Waters. Marine Biology 44: 71-76.

HUXLEY, J.S. AND G. TEISSIER. 1936. Terminology of relative growth. Nature 137: 780-781.

KAISER, M.F., A.S. AMIN AND H.A. ABOULELA. 2009. Environmental Hazards in the El-Temsah Lake, Suez Canal District, Egypt. Advances in Geoscience and Remote Sensing, Gary Jedlovec (Ed.), ISBN: 978-953-307-005-6, Available from: http://www.intechopen.com/books/advancesin geoscience and/remote-sensing/environmental hazards in the Temsah lake suez canal district egypt.

KATSANEVAKIS, S. 2007. Growth and mortality rates of the fan mussel Pinna nobilis in Lake Vouliagmeni (Korinthiakos Gulf, Greece): a generalized additive modelling approach. Marine Biology 152: 1319-1331. 
KELLER, N., D. DEL PIERO AND A. LONGINELLI. 2002. Isotopic composition, growth rates and biological behaviour of Chamelea gallina and Callista chione from the Gulf of Trieste (Italy). Marine Biology 140: 9-15.

KETCHEN, K.S., N. BOURNE AND T.H. BUTLER. 1983. History and present status of fisheries for marine fishes and invertebrates in the Strait of Georgia, British Columbia. Canadian Journal of Fisheries and Aquatic Sciences. 40: 1095-1119.

KILADA, R. 2010. Validated age and growth estimates of two clam species in a saltwater lake on the Suez Canal in Egypt. Egyptian Journal of Aquatic Biology and Fisheries 14(2): 111-126.

LEONTARAKIS, P.K. AND C.A. RICHARDSON. 2005. Growth of the smooth clam, Callista chione (Linnaeus, 1758) (Bivalvia: Veneridae) from the Thracian Sea, northeastern Mediterranean. Journal of Molluscan Studies 71(2): 189-192.

Linnaeus, C. 1758. Systema Naturae per regna tria naturae, secundum classes, ordines, genera, species, cum characteribus, differentiis, synonymis, locis. Editio decima, reformata. Laurentius Salvius: Holmiae. ii, 824 pp., available online at http://www. biodiversitylibrary.org/item/10277\#page/3/mode/1u $\mathrm{p}$ [details]

METAXATOS, A. 2004. Population dynamics of the venerid bivalve Callista chione (L.) in a coastal area of the eastern Mediterranean. J. Sea Res. 52: 293 305.

MOURA, P., M.B. GASPAR AND C.C. MONTEIRO. 2009. Age determination and growth rate of a Callista chione population from the southwestern coast of Portugal. Aquatic Biology 5: 97-106.

MUNRO, J.L. AND D. PAULY. 1983. A simple method for comparison the growth of fishes and invertebrates. Fishbyte 1: 5-6.

OSMAN, M.H. 2016. Biological and Fisheries Studies on Barracuda Fish (Family: Sphyraenidae) in the Gulf of Suez. Ph.D. thesis, Faculty of science, Suez Canal University.

PALMER, A.R. 1990. Effect of crab effluent and scent of damaged conspecifics on feeding, growth and shell morphology of the Atlantic dogwhelk Nucella lapillus (L). Hydrobiologia 193: 155-182.

PAULY, D., 1986. On improving operation and use of the ELEFAN programs. Part II. Improving the estimation of L. ICLARM. Fishbyte 4(1): 18-20.

PEHARDA, M., C.A. RICHARDSON, I. MLADINEO, S. ŠESTANOVIĆ, Z. POPOVIĆ, J. BOLOTIN AND N. VRGOČ. 2007. Age, growth and population structure of Modiolus barbatus from the Adriatic. Marine Biology 151(2): 629-638.

RICKER, W.E. 1975. Methods for assessment of fish production in fresh water. Second edition I. B. P. Hand book No. 3 Blackwell scientific publication, Oxford.

SAAD EL-DIN, M. 2014. Biodiversity and molecular identification of aquatic macro-invertebrates as biological indicators of toxic stress in Lake Timsah, Egypt. Ph. D. thesis. Faculty of Science, Suez Canal University.

SPARRE, P. AND S.C. VENEMA. 1992. Introduction to tropical fish stock assessment, Part 1 manual. FAO Fisheries Technical Paper 306/1: 376 pp.

TAYLOR, C.C. 1960. Temperature, growth and mortality-the Pacific cockle. International Council for the Exploration of the Sea (ICES) Journal of Marine Science. 26: 117-124.

TIRADO, C., C. SALAS AND J.I. LÓPEZ. 2002. Reproduction of Callista chione L., 1758 (Bivalvia: Veneridae) in the littoral of Malaga (southern Spain). Journal of Shellfish Reserch 21: 643-648.

VALLI, G., E. BIDOLI, AND C. MARUSSI. 1983. Osservazioni preliminari sulla riproduzione e sulla biometría di Callista chione (L.) (Mollusca: Bivalvia) del Golfo di Trieste. Nova Thalassia 6: 97-103.

VALLI, G., P. NODARI AND G. ZECCHINI-PINESICH. 1981. Statistical observation on fishing of Chamelea gallina (L.) and other mollusca bivalvia and gastropoda of Gulf of Trieste. Nova Thalassia 5: 75-96.

VON BERTA1ANFFY, L. 1938. A quantitative theory of organic growth. Human Biology 10: 181-213.

WILBUR, K.M. AND G. OWEN. 1964. Growth. In: Physiology of mollusca, (ed. K.M. Wilbur and C.M. Yonge). 1: 211-242. Academic Press, New York. 


\title{
النمو والخصائص المورفولوجية لعشائر Callista chione في بحيرة التمساح بقناة السويس، مصر
}

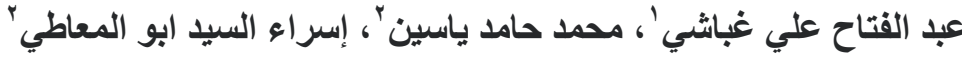

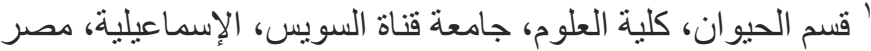

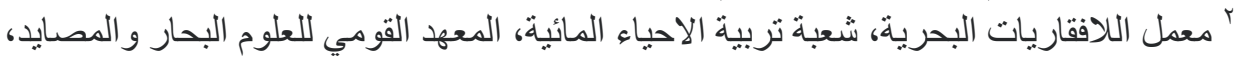

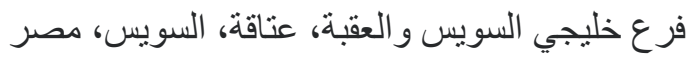 \\ الملخص العربي
}

يعد المحار من الرخويات ثنائية المصر اعين ويعتبر أكثر الحيوانات إنتشاراً من بين الكائنات الحية في بحيرة التمساح بقناة السويس، من حيث النوع و العدد. تركز هذه الدر اسة على محار كالستا كيون و التي تعد المحاولة الأولى لدراسة بعض الجوانب البيولوجية لهذا النوع. اهتمت الدر اسة بدر اسة الصفات البيولوجية للنوع إعتماداً علي توزيع التكر ار الطولي لمحار كالستا كيون بيحيرة التمساح وذلك التك لتحديد المجاميع العمرية المختلفة ومعاملات النمو والنفوق ومعدلات الإستغلال، كما اهتمت بالتحقق من النسبة بين الجنسين و الطول عند بداية النمو الجنسي وتحديد مراحل النضج الجنسي للمناسل وتحديد موسم التكاثر بواسطة إجراء فحص مجهرى لقطاعات نسيجية نم تحضير ها للمناسل.

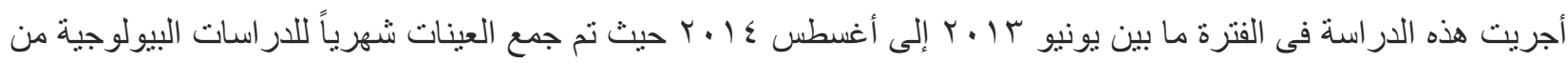
بحيرة التمساح. بلغ عدد العينات التي تم جمعها خلال فترة الدراسة بسعب عينة. تم تحديد بعض العلاقات المورفومترية (المظهرية) لمحار كالستا كيون و التى بدور ها لها أهمية فى الأبحاث البيولوجية السمكية و أظهرت جميع العلاقات المورفومترية وجود علاقة تنامى سلبية مشيرة إلى أن الدالة (س) أسرع في النمو نسبياً من الدالة (ص). تم إستخدام برنامج (FISATII) لحساب المجاميع العمرية ومعاملات النمو و النفوق ومعدلات الإستغلالحيث استخدمت الصيغ المتوفرة بالبرنامج لتحليل بيانات التكرار الطولي لمحار كالستا كيون التي تم رصدها خلال فترة الدراسة. استخدمت طريقة تحليل التطور الثكلي Battacharya’s method)

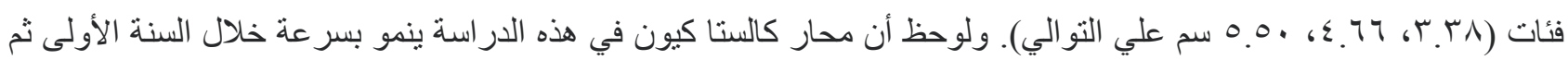

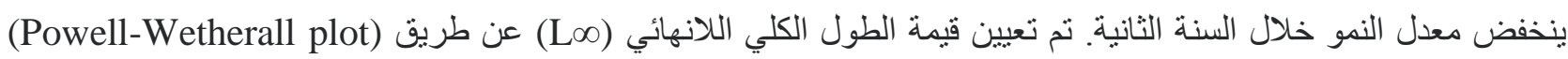
لتكون هY.7 سم، وأيضاً حساب معامل النمو(K) عن طريق Electronic Length Frequency Analysis model

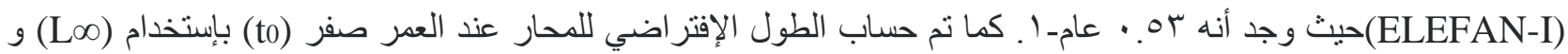

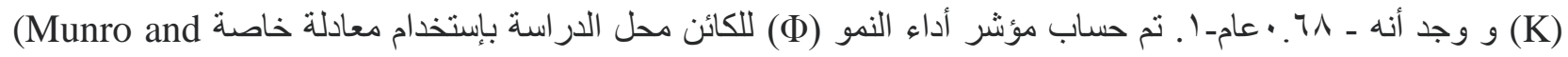
و و و و و و الطبيعي (Zauly equation)

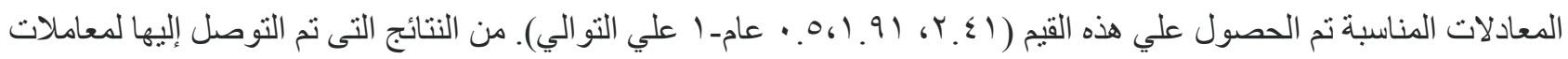

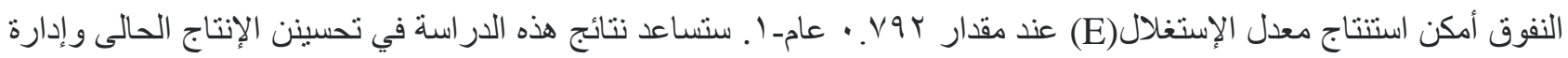
المصيد ووضع قاعدة و أساس للتربية. 